\title{
TERAPI NUTRISI PADA PENYAKIT KANKER PANKREAS
}

Aryanti R. Bamahry ${ }^{1,2}$, Agussalim Bukhari ${ }^{2}$, R. Satriono ${ }^{2}$, A. Yasmin Syauki ${ }^{2}$

${ }^{1}$ Bagian Ilmu Fisiologi, Fakultas Kedokteran, Universitas Muslim Indonesia

${ }^{2}$ Bagian Ilmu Gizi Klinik, Fakultas Kedokteran, Universitas Hasanuddin

\section{PENDAHULUAN}

Kanker pankreas relatif jarang ditemukan, sekitar 2,5\% dari seluruh jenis kanker di dunia. Namun, karena angka mortalitas yang tinggi dengan angka harapan hidup dalam 5 tahun $<5 \%$ dan rata-rata harapan hidup 4,5 bulan (stage IV) dan 24,1 bulan (stage IA) sehingga kanker pankreas merupakan penyebab kematian kelima terbanyak di negaranegara maju termasuk Amerika Serikat dan Eropa. American Cancer Society memper-kirakan pada tahun 2017 terdapat 53.670 orang (27.970 pria dan 25.700 wanita) akan didiagnosis dengan kanker pankreas dan 43.090 orang (23.300 pria dan 20.790 wanita) akan meninggal karena kanker pankreas di Amerika Serikat (Bodmer 2012, American Cancer Society 2016). Kegagalan terapi konvensional kanker pankreas dibuktikan dengan dengan angka harapan hidup 18\% dalam 1 tahun dan $4 \%$ dalam 5 tahun. Lebih dari $98 \%$ penderita kanker pankreas akan meninggal dunia dan sebagian besar pasien yang menderita kanker pankreas meninggal dalam enam bulan setelah diagnosis ditegakkan. Prognosis yang buruk ini karena ketidakmampuan mendiagnosis kanker pankreas pada stadium awal. Pankreas yang terletak jauh di dalam tubuh, sehingga tumor tidak dapat dilihat atau dirasakan oleh dokter selama pemeriksaan fisik rutin. Pasien biasanya tidak memiliki gejala sampai kanker telah menyebar ke organ lain. Keluhan dan gejala mulai timbul ketika kanker sudah dalam stadium lanjut dan metastasis ke nodus limfe regional dan organ-organ sekitar bahkan organ yang jauh (Thomson 2007, Steriti, Redlich 2003).

\section{ETIOLOGI DAN PATOGENESIS}

Usia lanjut, merokok, genetik merupakan faktor risiko mayor kanker pankreas, sedangkan alcohol, diet tinggi lemak adalah faktor risiko minor. Risiko kanker pankreas 2,5-3,6 kali pada perokok dibanding bukan perokok. Nitrosamin dalam tembakau diper-kirakan sebagai agen kausatif dalam patogenesis terjadinya kanker. Obesitas, diabetes mellitus, pankreatitis kronik juga menjadi faktor risiko kanker pankreas. Paparan berat di tempat kerja untuk pestisida 
tertentu, pewarna, bahan kimia yang digunakan dalam pemurnian logam dapat meningkatkan risiko terkena kanker pankreas. Risiko kejadian kanker pankreas empat sampai lima kali pada individu yang terekspos DDT (dichlorodiphenyltrichlo-roethane).

Jumlah kanker pankreas juga meningkat pada orang-orang yang minum air yang mengandung klorin (Thomson 2007, Redlich 2003, American Cancer Society 2016, Hidalgo 2010, Huhmann 2008).

Seperti penyakit keganasan lain, kanker pankreas adalah penyakit mutasi genetik. Defek genetik termasuk aktivasi KRAS2 oncogene dan inaktivasi gen tumor-suppressor (CDKN2A, TP53) serta hilangnya DPC4. Transkripsi mutan gen KRAS akan menghasilkan protein Ras abnormal yang menyebabkan proliferasi abnormal sel (gambar 1). IInaktivasi CDKN2A akan menyebabkan hilangya protein p16 (regulator siklus sel transisi G1-S) sehingga proliferasi sel meningkat. Inaktivasi TP53 menyebabkan kerusakan DNA sel dan sinyal apoptosis dan akhirnya berkontribusi terhadap instabilitas gen. Sedangkan hilangnya DPC4 akan menyebabkan sinyal abnormal transforming growth faktor $\beta$ (TGF- $\beta$ ) cell-surface receptor (Redlich 2003, Hidalgo 2010).

\section{TANDA DAN GEJALA KLINIK}

Gejala utama kanker pankreas adalah nyeri perut, ikterus dan penurunan berat badan. Gejala spesifik

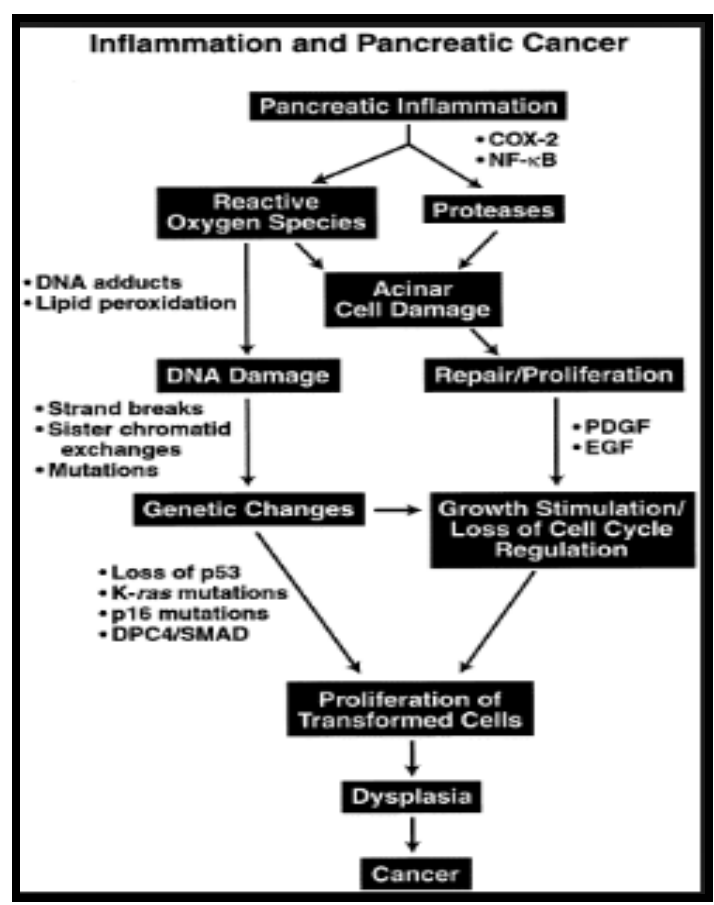

Gambar 1. Patogenesis kanker pankreas (Farrow, 2002)

yang lain termasuk kembung, mual dan muntah, anoreksia dan asthenia. Penurunan berat badan yang cepat dan progres merupakan gejala yang paling sering muncul pada kanker pankreas. Sekitar 90\% pasien mengeluhkan nyeri pada epigastrium, menjalar ke belakang. Ikterus merupakan gejala yang tampak pada sekitar $30 \%$ pasien, Ikterus lebih banyak ditemukan pada kanker kaput pankreas, namun obstruksi atau ikterus bisa juga merupakan akibat dari metastasis kanker ke hati atau nodus limfe 
di sekitar kandung empedu. Sekitar 8090\% kanker pankreas terjadi disfungsi eksokrin dan malabsorpsi yang berhubungan dengan kehilangan sekresi normal enzim pankreas akibat obstruksi duktus pankreas oleh tumor kaput pankreas atau akibat hilangnya fungsi parenkim pankreas oleh destruksi progresif dan perkembangan tumor. Hilangnya jaringan pankreas akibat operasi juga berkontribusi terhadap exocrine pankreas insufficiency (EPI). Gejala EPI adalah diare, steatore dan azotorrhoe (selanjutnya malabsorpsi zat gizi dan malnutrisi), penurunan berat badan, dispepsia, meteorismus, nyeri, defisiensi vitamin larut lemak, overgrowth bakteri (Solvay, 2003). Gejala seperti kandung empedu yang bisa teraba, massa di perut dan edema jarang dijumpai. Tromboflebitis terjadi pada sekitar 10\% pasien (Thomson 2007, Hidalgo 2010).

Pada pemeriksaan fisik ditemukan ikterus, temporal wasting, limfadenopati perifer, hepatomegali dan ascites. Tes darah rutin umumnya tidak spesifik dan mungkin terdapat gangguan fungsi hati, hiperglikemia dan anemia. (Hidalgo, 2010, National Cancer Institute 2010)

\section{KANKER PANKREAS} MALNUTRISI
Satu dari komorbiditas yang berhubungan dengan kanker adalah malnutrisi dan hal ini berhubungan dengan risiko komplikasi, meningkatnya lama rawat inap di rumah sakit dan mortalitas. Semua ini membutuhkan biaya yang besar. Karena itu, sangat penting untuk memahami bagaimana kanker mempengaruhi metabolisme untuk mencegah menurunnya status gizi yang akan mempengaruhi perkembangan penyakit Kaheksia umumnya terjadinya pada semua kanker akibat katabolisme jaringan, gangguan zat gizi dan malabsorpsi pada stadium lanjut. Kanker pankreas unik, berbeda dengan kanker lain karena penurunan berat badan dan malabsorpsi terjadi sekitar $80-90 \%$ pada pasien saat didiagnosis (Correia M 2007; Damerla, 2008)

Perubahan yang terjadi pada sistem metabolisme nampak pada defisit kalori sekitar $300 \mathrm{kkal} / \mathrm{hari}$ pada pasien kanker. Kanker menyerap glukosa dalam jumlah yang besar dan mengubahnya dalam bentuk laktat. Sementara tekanan oksigen sangat rendah untuk dipakai dalam siklus Krebs dan fosforilasi oksidatif mitokondria, laktat yang diproduksi kemudian dibawa ke hati dan dikonversi menjadi glukosa dalam Cori \& Cycle. Walaupun Cori cycle merupakan respon normal pada sekitar $20 \%$ 
penggantian glukosa, jumlah ini meningkat pada pasien kanker yang kaheksia sampai 50\%, dengan produksi laktat $\quad 60 \%$. Glukoneogenesis menggunakan 6 molekul ATP untuk setiap siklus laktat-glukosa dan ini menjadi tidak efisien, yang berkontribusi pada meningkatnya resting energy expenditure (REE) pada pederita yang kaheksia (Correia M, 2007; Arends J, 2006).

\section{DIAGNOSIS}

Diagnosis kanker pankreas ditegakkan berdasarkan gejala yang ditemukan terutama nyeri perut, ikterus dan penurunan berat badan. Pemerik-saan laboratorium didapatkan kadar bilirubin, enzim hati dan tumor marker CA 19-9 yang meningkat. Pemeriksaan penunjang lain seperti CT Scan dengan kontras untuk menilai stadium kanker dan adanya metastasis. Pemeriksaan endoscopic ultrasound sangat baik dalam menemukan tumor-tumor kecil di pankreas (Kusumayanti 2008).

\section{TERAPI NUTRISI}

Tindakan reseksi termasuk pankreatektomi atau pankreatoduo-denal, potensial memberikan kelang-sungan hidup yang lebih lama pada kanker pankreas yang terlokalisir. Namun sampai saat ini, $75-80 \%$ pasien dengan kanker yang unresectable. Kemoterapi adjuvan dikombinasi dengan radioterapi, termasuk 5-fluorouracil (5-FU), telah menunjukkan efek yang minimal terhadap kelangsungan hidup. Terapi radiasi dianjurkan pada tumor yang lebih besar dan manajemen nyeri. Nutrisi yang adekuat menjadi faktor yang ikut berperan dalam suksesnya terapi pada pasien kanker. Tujuan dari terapi nutrisi adalah untuk mengatur asupan nutrisi berdasarkan gejala penyakit, memper-tahankan status gizi sehingga mampu menghadapi stress metabolik (pembedahan, radioterapi, kemoterapi), meminimalkan efek samping terapi serta memperbaiki kualitas hidup (Thomson 2007, Redlich 2003, Liu Ch 2011, Satriono 2011).

Pada pasien kanker pankreas terjadi defisit kalori sebesar $300 \mathrm{kkal} / \mathrm{hari}$. Defisit ini dikompensasi dengan memperbaiki asupan suplemen kalori dan protein yang disesuaikan dengan kebutuhan pasien. Beberapa penelitian terbaru merekomendasikan suplemen padat kalori dan protein yang lebih tinggi (Coreia, 2007; Komanduri, 2008; Kumar, 2011). Metode pemberian nutrisi melalui oral merupakan pilihan pertama dengan memperhatikan perubahan fungsi pengecapan, selera makan, derajat kekenyangan, adanya nyeri dan depresi. Dianjurkan makan sayuran dan buah lebih 
dari 5 porsi (terutama biji utuh), membatasi daging merah yang banyak mengandung lemak, membatasi konsumsi alkohol dan menyeimbangkan asupan kalori dan aktivitas fisik. Nutrisi enteral melalui tube feeding diberikan bila asupan oral tidak adekuat. Sementara nutrisi parenteral merupakan pilihan apabila saluran cerna tidak dapat digunakan (obstruksi saluran cerna) dan pada pasien pre-operatif dengan kehilangan berat badan $15-20 \%$ dan tidak dapat diberikan nutrisi enteral secara adekuat. Pemberian lemak harus diperhatikan jumlahnya karena adanya malabsorpsi lemak akibat defisiensi enzim lipase sebagai efek dari kanker pankreas, kurang dari 30\% kalori total. Sumber lemak sebaiknya yang berasal dari bahan nabati, yang mengandung lebih banyak asam lemak tak jenuh dibandingkan asam lemak jenuh. Sementara asupan protein bisa ditingkatkan antara 0,8-2,5 $\mathrm{g} / \mathrm{kgBB}$, disesuaikan dengan keadaan pasien. Sebagai sumber protein sebaiknya diperoleh dari ikan, ayam (terutama daging dada), tahu dan tempe, karena tidak banyak mengandung lemak. Rekomendasi asupan karbohidrat 45- 60\% dari kalori total tergantung dari adanya insufiensi endokrin. Karbohidrat yang diberikan berupa karbohidrat kompleks. Asupan serat diusahakan paling tidak 25 gram/hari. Di samping akan membantu menghambat penyerapan lemak, makanan sumber serat seperti sayur dan buahbuahan segar umumnya kaya akan vitamin dan mineral (Kumar, 2011; Grant, 2008; Satriono, 2011; Damerla, 2008).

Suplementasi enzim pankreas diperlukan karena disfungsi eksokrin dan malabsorpsi yang berhubungan dengan kehilangan sekresi normal enzim pankreas. Suplementasi enzim pankreas ini seringkali dapat mengurangi gejala-gejala gastro-intestinal pada kanker pankreas, meningkatkan asupan makan dan memperbaiki status gizi (Keller J, 2005; Damerla. 2008; Friess, 1993). Studi oleh Bruno dkk, 1998 menunjukkan bahwa terapi pengganti enzim pankreas dapat memperbaiki penurunan berat badan pada pasien tersebut. Studi terakhir pada tikus dengan kanker pankreas oleh Saruc dkk, 2004 juga menunjukkan peningkatan angka harapan hidupnya. Rekomendasi lipase yaitu 25.000-40.000 IU/makan. Cara pemberian adalah selama makan, seperti contoh : $1 \mathrm{kapsul} / \mathrm{tablet}$ pada awal makan, 2 kapsul/tablet selama makan dan 1 kapsul/tablet segera setelah makan (Pongprasobchai, 2005).

\section{KESIMPULAN}


Pemberian terapi paliatif dan dukungan nutrisi yang adekuat pada kanker pankreas ditujukan untuk memperbaiki keadaan umum, mempertahankan status gizi dan memperbaiki kualitas hidup pasien. Diperlukan suplementasi enzim pankreas pada kanker pankreas untuk mengurangi gejala-gejala gastro-intestinal, mengatasi malabsorpsi dan memperbaiki status gizi.

\section{DAFTAR PUSTAKA}

American Cancer Society. Pancreatic Cancer. 2012. Available at: http://www.cancer.

org/acs/groups/cid/documents/webcont ent/003131-pdf.pdf

Arends J, Bodoky G, Bozzetti F, Fearon K, Muscaritoli M, Selga G, ESPEN Guidelines on Enteral Nutrition: Nonsurgical oncology. Clinical Nutrition. 2006; 25, 245-259.

Bodmer M, Becker C, Meier C, Jick SS, Meier CR. Use of antidiabetic agents and the risk of pancreatic cancer : a case-control analysis. $A m \quad J$ Gastroenterol. 2012; 107: 620-626.

Correia MI. Cancer-related Nutrition. Europan Oncological Disease. 2007: 113-116.

Damerla V, Gotlieb V, Larson H, Saif
MW. Pancreatic Enzyme Supplementation in Pancreatic Cancer. $J$ Support Oncol. 2008;6:393-396.

Farrow B, Evers BM. Inflammation \& pancreatic cancer. Surgical oncology. 2002; 10)4): 153-169.

Friess H, Böhm, Ebert M, Büchler M. Enzym treatment after gastro-intestinal surgery. Digestion. 1993. 54(Suppl.2): 48-53.

Grant B. Medical Nutrition Therapy for Cancer in Krause's Food and Nutrition Therapy, 959-84. 2008.

Hidalgo M. Pancreatic cancer. $N$ Eng $J$ Med. 2010; 362 : 1605-17.

Keller J, Layer P. Human pancreatic exocrine response to nutrients in health and disease. Gut. 2005. 54 (sup VI): vi1-28.

Kumar NB, Nutritional Management of Cancer Treatment Effects, DOI 10.1007/978-3-642-27233-2_2, 2012.

Kusumayanti et al. Problems ini Diagnosis Approach for Carcinoma of Pancreatic Head. The Indonesian Journal of Gastroenterology, Hepatology and Digestive Endoscopy. Volume 9. Number 2. August 2008.

Liu $\mathrm{Ch}$, et al. Enteral nutrition is superior to total parenteral nutrition for pancreatic cancer patients who underwent Pancreaticoduodenectomy. 
Asia Pac J Clin Nutr 2011;20 (2):154160.

National Cancer Institute. What you need to know about cancer of the pancreas. U.S. Department of Health and human services. National Institutes of Health. 2010.

Pongprasobchai S. Pancreatic enzymes : appropriate use in clinical practice. Thai J gastroenterol. 2005. 6 (3): 158166.

Thomson ABR. The Pancreas in First Principles of Gastroenterology. Fifth Edition. Janssen-Ortho. 2007

Redlich et al. Tumors of the Pancreas, Gallbladder and Bile Ducts in Clinical Oncology. Third Edition 2003.

Satriono R, Taslim NA, Hadju V, Bukhari A, Titus J, Rasyid H. Kanker Pankreas. Dalam: Standar Pelayanan Medis Gizi Klinis. Bagian Gizi Klinis FK-Unhas. Maksssar. 2011. hal. 219-226.

Solvay Pharmaceutical GmbH. Enzyme replacement therapy- a therapeutic regimen for pancreatic exocrine insufficiency. Business briefing : European Pharmaco-therapy. 2003 : $1-4$.

Steriti R. Pancreatic cancer. http:// www.naturdoctor.com/Chapters/Resea rch/PancreaticCancer.pdf.
Thomson ABR. The Pancreas in First Principles of Gastroenterology. Fifth

Edition. Janssen-Ortho. 2007 

